\title{
Ortaöğretim Öğrenci Velilerinin Tarih Dersinden Beklentileri (Yozgat îli Örneği) ${ }^{*}$
}

\author{
The Expectations of High School Students' Parents from History Lesson (The
} Example of Yozgat Province)

\section{Recep TURGUT}

MEB, E-Posta: ryesturgut@gmail.com

orcid.org/0000-0001-9399-7513

Article Info

\begin{tabular}{c|l}
\hline $\begin{array}{c}\text { Article Type } \\
\text { Received }\end{array}$ & $\begin{array}{l}\text { Research \& Theoretical } \\
\text { Accepted }\end{array}$ \\
DOI & $\begin{array}{l}11.12 .2019 \\
\text { Co.17497/tuhed.658227 } \\
\text { Author }\end{array}$ \\
Cite & $\begin{array}{l}\text { Turgut, R. (2020). Ortaöğretim öğrenci velilerinin tarih dersinden } \\
\text { beklentileri (Yozgat ili örneği). Turkish History Education Journal, } \\
9(1), \text { ss. 132-151. DOI: 10.17497/tuhed.658227 }\end{array}$ \\
\hline
\end{tabular}

\footnotetext{
*Bu makale "Ortaöğretim Tarih Eğitiminde Verimliliğin Sistem Yaklaşımı Çerçevesinde Incelenmesi” isimli doktora tez çalışmasının bir parçasıdır ve 10-12 Ekim 2019 yılında Bolu'da düzenlenen 6. Uluslararası Tarih Eğitimi Sempozyumunda Sözlü Bildiri olarak sunulmuştur.
} 
Öz: Bir öğrencinin eğitimsel başarısına, verimliliğine etki eden faktörlerden biri de velisidir. Ortaöğretim tarih eğitiminde öğrenci, öğretmen, müfredat, okul vb. etkenlerle birlikte öğrenci velileri de bu eğitimi etkileyen unsurlardan birisidir. Bu araştırmanın amacı ortaöğretim öğrenci velilerinin çocuklarının tarih dersinden hangi bilgi, beceri ve değerleri kazanmalarını beklediklerini ortaya koymaktır. Araştırma Yozgat il merkezi ile Yerköy ve Sorgun ilçeleri dahil olmak üzere toplam 15 ortaöğretim kurumunda gönüllü olan 983 öğrenci velisi ile yarı yapılandırılmış veri toplama formu yoluyla gerçekleştirilmiştir. Çalışmada fen, Anadolu, imam-hatip ve mesleki liseler şeklinde farklı türdeki ortaöğretim kurumları belirlenmiş ve velilere lisede tarih dersi alan çocuklarından hangi bilgi, beceri ve değerleri kazanmalarını bekledikleri sorulmuştur. Elde edilen veriler içerik analizi yöntemiyle incelenmiş ve elde edilen bulgular kodlanarak temalandırıımıştır. Bu temalar Türk tarih bilgisi, tarih bilinci, vatanseverlik, milli değerler şeklinde bilgi ve değer kazanımlarına yoğunlaşmaktadır. Araştırma sonuçları velilerin bilgi ve değer yönünden beklentilerinin çok yüksek olduğunu ancak beceri boyutuyla ilgili beklenti düzeylerinin çok düşük olduğunu göstermektedir. Değer

Anahtar Kelimeler: Ortaöğretim Tarih Eğitimi, Veli Beklentileri, Verimlilik, Bilgi, Beceri,

\begin{abstract}
One of the reasons that affect students' productivity and educational success is his/her parents. In history teaching of high education, parents are one of the reasons for student, teacher, curriculum and school etc. The objective of the research so reveals that which knowledge, skill and values parents want their children to acquire in history teaching of high education. This research includes 15 high education institutions, 983 volunteer parents, by using semi-structured data collection forms in Yerköy, Sorgun, and Yozgat city center. It is decided that different kinds of institutions such as science, Anatolia, imam-orator and vocational high school be in the research. Parents were asked what information, skills, and values they expected from their children who took history lessons in high school. Data were analyzed by the content analysis method and the findings were coded and themed. These themes concentrate on knowledge and value gains in the form of Turkish historical knowledge, historical awareness, patriotism, and national values. The results of the research show that the expectations of the parents in terms of knowledge and value are very high, but their level of expectation about the skill dimension is very low.
\end{abstract}

Keywords: History Education, Expectations of Parents, Productivity, Knowledge, Skill, Value

\title{
Extended Summary
}

\section{Purpose}

The general aim of this study is to reveal parents' expectations for high school history lessons. Within the framework of the general purpose of the research, parents' opinions about what knowledge, skills, and values students should gain in history lessons were put forward and these were combined under certain themes.

\section{Method}

In this study, the qualitative research paradigm was adopted and the opinions of high school students' parents were taken. Findings obtained by using a semi-structured data collection tool were coded by content analysis and these codes were themed. In this way, it is 
aimed to conceptualize the data and reveal the themes that will define the phenomenon. The results are presented in a descriptive narrative and direct quotations are frequently included (Yıldırım \& Şimşek, 2018).

For the research, 15 official high schools were identified across Yozgat in the 20182019 academic year. Semi-structured data collection forms consisting of 3 open-ended questions were sent to the parents of students through history teachers working in these schools and data was collected from 983 parents. To apply their views on the history lesson and analyze their answers, parents were asked what information, skills, and values would you expect from their children who had 4 years of history in high school.

\section{Results and Discussion}

Within the framework of the data obtained after the study, the expectations of the parents from history lessons within the framework of a total of 6 themes emerge. These themes are Turkish Historical Information, Information General History, Historical Awareness, Patriotism, National Values, and Historical Thinking Skills'.

The expectation of 864 parents who participated in the study is coded as "Knowing the Turkish History". 170 parents are coded under the heading of "Knowing the Difficulties in the Past", 112 parents are "Knowing the Culture, Customs, and Traditions", and 79 parents are "Ottoman History". 40 parents also "Ataturk" in expectations is encoded with the title. Under the theme of General History Information, 74 parents are in the expectation coded under the heading "History Information", 54 parents "World History and Other Civilizations", 50 parents "Wars".

Expectations of parents about Historical Thinking Skills are coded under 3 headings. These are "Access to Objective History Knowledge", "Interpretation of Historical Events" and "Historical Empathy ". However, these expectations were stated by very few parents.

The expectations of the parents regarding the value dimension are themed under the title of "Historical Awareness", "Patriotism" and "National Values". Under the theme of Historical Awareness, 231 parents are within the expectation coded under the heading "Taking Lessons from the Past", 202 parents with the heading "Knowing the Past" and 117 parents are "Historical Awareness / National Awareness". Under the theme of patriotism, 163 parents are in the expectation coded under the heading "Loving Homeland / Nation", 40 parents "Being Beneficial to Homeland and Nation" and 22 parents "Love of Flag". Under the National Values theme, it is seen that 180 parents are within the expectation coded under the title of "Having National / Spiritual / Moral Values".

\section{Conclusion}

In this study, the parents of high school students were asked what information, skills, and values they expected to gain from their children who took history lessons for 4 years, and as a result of the study, it was seen that the parents list their expectations in terms of knowledge and value, and it was determined that the expectations of the student parents regarding the skill were limited. 
Almost all of the parents who participated in the research want their children to know the Turkish history. Parents' emphasis on Turkish history is also in line with the objectives of the history curriculum. their parents' expectations under the Information heading "Culture, Customs and Traditions, Ottomans, Ataturk, Turkey, Ataturk's Principles and Revolutions, Sultans, Seljuk History and the Turkish-Islamic History" is in the other expectations entering the Turkish history subject.

Under the information heading, the highest rate of parents under the theme of "General History Information" constitutes the expectation of historical information. Also, world history, wars, recent history knowledge, chronology knowledge, and Islamic history are in other expectations. The highest expectation exists within the heading of values, except for the expectations regarding Turkish historical knowledge. Within this heading, "Taking lessons from the past" is the expectation that parents emphasize most. Parents think that history learning is aimed at providing lessons from the past.

Apart from this, the parents under the title of "Guiding the Future by Knowing the Past", "Loving the Homeland, the Nation", "History Consciousness / National Consciousness", "Being Beneficial to the Country and the Nation", "The Idea of National Unity and Togetherness and Feeling of Citizenship" and "Love of Flag". They listed their expectations under the title of "Value". Almost all of the expectations highlighted in values are directly related to the value of "patriotism" counted in root values in the curriculum.

In both historical thinking skills and more inclusive history literacy skills, a teaching process based on various methods and techniques is envisaged to activate the student in the learning process (Keçe, 2015: 116). After this study, it was concluded that very few parents' expectations were directed towards historical thinking skills. These expectations stated by a limited number of parents are access to objective history information, interpretation of historical events and historical empathy.

As a result, while parents have high expectations in terms of knowledge and value, this expectation is limited in terms of skill. Also, it is seen that, in terms of general objectives in the curriculum, the skill dimension and parent expectations do not overlap. Harmony between parents' expectations and curriculum objectives will also increase the productivity desired in history classes. This study is limited to Yozgat province. It can be said that similar studies to be carried out in different provinces are needed.

\section{Giriş}

Eğitim sisteminin en önemli unsurlarından birisi öğrenci velisidir. Velilerin öğrenci, okul, öğretmen ve ders ile ilişkileri sistemin verimliliği üzerinde büyük etkiye sahiptir. Özellikle velilerin okul dışında öğrenciye örnek teşkil etmesi, onları güdülemesi, yönlendirmesi söz konusudur. Yılmaz ve Sarpkaya'nın da (2016) vurguladığı gibi kaliteli eğitimde sadece okul değil, kişinin içinde bulunduğu çevre de etkili olmaktadır. 
Okul, aile ve öğrenci bir çarkın dişlileri gibidir. Bir dişlide meydana gelebilecek bir hasar ister istemez diğer dişlileri de etkilemektedir. Bunun için bu üçlü birbirinden ayrı tutulamaz ve eğitimimizin temel yapı taşlarıdır. Eğitim süreci içerisinde veli, eğitim kurumunun dışında en önemli katkıyı sağlayan ve büyük oranda belirleyici olan taraftır denilebilir (Arslanargun, 2007: 120; Şahin, 2018: 1-2).

Yapılan pek çok araştırma öğrenci başarısında veli faktörünün çok belirleyici olduğunu göstermektedir (Altun, 2009: 573; Argon ve Kıyıcı, 2012: 92; Babaoğlan, Çelikve Nalbant, 2018: 59; Döş, 2011: 85; Tatlığlu, 2016: 15). Öğrenci velilerinin beklentileri tüm eğitim kademelerinde öğrenci başarısını farklı oranlarda etkilemektedir. Bu beklentilerin öğretim programlarının amaçları ile uyumlu olması ise eğitim sisteminin verimliliğini artırıp azaltabilir. Çünkü hedefler belirlenirken toplumsal ihtiyaçlar dikkate alınır. Zira toplumlar bir değişim süreci yaşamaktadır. Bu değişimin hızı oranında toplumlar gelişmişliklerinin düzeyini belirleyebilmektedir (Topbaş, 1997: 1).

Belirlenen hedeflerin gerçekleştirilebileceği örgün eğitim kurumları okullardır. Eğitim sisteminin yetiştirmeyi düşündüğü insanlar, saptanan ilke ve amaçlar doğrultusunda okulda yetiştirilir. Planlanmış eğitim etkinliklerinin uygulanma, izlenme ve sınanma durumlarının tamamına yakın bir bölümü okul ortamında olanaklıdır (Dinçer, 2002: 36). Okullar bu hedefleri belirlenen öğretim programları yoluyla gerçekleştirmektedir.

Öğretim programları, 1739 sayılı Milli Eğitim Temel Kanunun da ifade edilen "Türk Milli Eğitiminin Genel Amaçları" ile "Türk Milli Eğitiminin Temel İlkeleri" esas alınarak hazırlanmaktadır. Liseyi tamamlayan öğrencilerin, ilkokulda ve ortaokulda kazandıkları yetkinlikleri geliştirmek suretiyle, millî ve manevi değerleri benimseyip hayat tarzına dönüştürmüş, üretken ve aktif vatandaşlar olarak yetiştirilmesi amaçlanmakta ayrıca ilgi ve yetenekleri doğrultusunda yükseköğretime ve hayata hazır bireyler olmaları sağlanmaktadır (MEB, 2018). Bu amaçları gerçekleştirmek için tarih dersleri de tüm ortaöğretim kurumlarında zorunlu ders olarak okutulmaktadır (TTKB, 2018).

Burada tarih derslerinin öğretiminin amaçlarının neler olduğuna bakmak gerekmektedir. Demircioğlu (2006), geçmişten günümüze tarih öğretiminin amaçlarında iki yaklaşımın bulunduğunu belirtmektedir. Bu amaçların ilkinde öğrencilere geçmişin bilgisi öğretilerek tarihini, toplumunu, değerlerini, kültürünü tanıyan iyi vatandaşların yetiştirilmesi amaçlanırken; ikincisin de öğrencilere bilimsel bakış açısı ve üst düzey düşünme beceri ve niteliklerinin kazandırılması amaçlanmaktadır. Dilek (2006), bu amaçların birincisini disiplin dışı amaçlar, ikincisini disiplin içi amaçlar şeklinde ifade etmektedir. "Yirminci yüzyılın son çeyreğinde gelişen yeni tarih öğretimi anlayışında bilgiden ziyade tarihsel düşünme becerileri ön plana çıkarılmış ve öğrencilere kanıt değerlendirme, eleştirel düşünme ve problem çözme gibi becerilerin kazandırılması hedeflenmiştir" (MEB, 2018). Bu süreçte sosyal bilgiler ve tarih derslerinin öğretim programları da değiştirilmiş ve programlarda öğrencilere hangi beceri ve değerlerin kazandırılacağı açık şekilde belirlenmiştir (Öztürk ve Mutlu, 2017: 553).

Tarih öğretim programlarında hem disiplin dışı amaçlar ve hem de disiplin içi amaçlar şeklinde özetlenebilecek öğretim hedefleri bir arada verilmektedir. Bu hedefleri tarihsel bilgi, 
tarihsel düşünme becerileri ile birlikte bilgi, beceri ve davranışların arasındaki bütünlüğü kuran değerler başığı altında sınıflandırabiliriz (MEB, 2018).

\section{Bilgi, Tarihsel Bilgi}

Bilgi, öğrenme, araştırma veya gözlem yolu ile elde edilen gerçek, malumat, vukuf olarak tanımlanmaktadır (TDK, 2019). Bilginin birinci özelliği, toplumsal gerçeği işlemesi, yansıtması, taşıyıp aktarmasıdır. "Bu vasfıyla bilgi aynı zamanda toplumun tarihsel birikimidir ve zaman içinde değişmekle birlikte bilgi, toplumun ya da en azından toplumsal bütün içindeki belirli bir grubun egemen görüşünü de simgelemekte, somutlamaktadır" (Anık, 2006: 6). Bilgi, kısaca, insanların ve toplumların, başta kendisi olmak üzere, çevresini bir zihni algılayış ve yorumlayış biçimidir (Aydın, 2008: 197).

Tarihsel bilgi geçmişte yaşanmış olayların günümüze aktarılmış şeklidir. Bu bilgiler erken yaşlardan itibaren edinilmeye başlanmaktadır (Karabağ, 2002: 212).

\section{Beceri, Tarihsel Düşünme Becerileri}

Beceri, Türk Dil Kurumu'na göre, kişinin yatkınlık ve öğrenime bağlı olarak bir işi başarma ve bir işlemi amaca uygun olarak sonuçlandırma yeteneği, maharet olarak tanımlanmaktadır (TDK, 2019). Tarih bilimine ilişkin beceriler ise, bunların, doğrudan zihinsel ya da entelektüel becerilerle ilişkili olması sonucu ortaya çıkmaktadır (ışık, 2008: 123).

Tarih öğretim programlarında "Alana Özgü Yeterlilik ve Beceriler" (MEB, 2018) başlığı altında yer alan ve tarihsel düşünme becerileri olarak ("Historical Thinking Standards", 2019) da isimlendirilen şu maddeler bulunmaktadır.
a. Kronolojik Düşünme Becerisi
b. Tarihsel Kavrama Becerisi
c. Neden-Sonuç İlişkisi Kurabilme Becerisi
d. Değişim ve Sürekliliği Algılama Becerisi
e. Tarihsel Sorgulamaya Dayalı Araştırma Becerisi
f. Tarihsel Analiz ve Yorum Becerisi
g. Tarihsel Sorun Analizi ve Karar Verme Becerisi
h. Geçmişe Geçmişteki İnsanların Bakış Açısıyla Bakabilme Becerisi veya Tarihsel Empati

\section{Değer}

Değer, belirli bir durumu bir diğerine tercih etme eğilimi olarak tanımlanmaktadır. Değerler, davranışlara kaynaklık eden ve onları yargılamaya yarayan anlayışlardır (Erdem, 2003: 56). Türk Dil Kurumu değer kavramını bir ulusun sahip olduğu maddi ve manevi unsurların bütünü olarak tanımlamaktadır (TDK, 2019). Çocuklar yaşamlarının çok erken yaşlarında aileleri, akranları ve diğer sosyal iletişim kanalları yoluyla değerleri öğrenmeye başlamaktadırlar (Healstead ve Taylor, 2000: 169).

"Çağımızda tarih eğitimine ağırlıklı olarak zihinsel becerileri geliştirme görevi yüklenmişse de tarih eğitimi, vatandaşlık ve değer eğitimini destekleyebilecek önemli bir alandır. Geleneksel olarak ifade edilen ve daha çok sosyal amaçları ön plana çıkaran yaklaşım; milli, manevi, kültürel değerleri vurgularken, çağdaş yaklaşım olarak nitelenen ve disiplin içi 
amaçları vurgulayan yaklaşımda ise bilimsel, demokratik değerler ve insan hakları daha çok vurgulanmaktadır" (Demircioğlu ve Tokdemir, 2008).

Ortaöğretim programlarında "kök değerler" başlığı altında 10 adet değer belirlenmiştir. Bunlar; adalet, dostluk, dürüstlük, öz denetim, sabır, saygı, sevgi, sorumluluk, vatanseverlik, yardımseverlik' tir (MEB, 2018).

Ülkemizde ilgili alanyazın incelendiğinde ortaöğretim tarih dersleri ve öğretim programları ile ilgili öğretmen ve öğrenci görüşlerine dayalı çok sayıda araştırma bulunmaktadır (Demircioğlu, 2006; Safran, 2006; Tekeli, 2017; Turan, 2015). Ancak bu konuda ortaöğretim tarih derslerinde veli görüşlerine ya da beklentilerine dayalı yapılan araştırmalar bulunmamaktadır. Yapılan literatür taramasında bu konuda illköğretim düzeyinde velilerin farklı beklenti düzeylerini ve eğitime etkilerini belirlemeye yönelik yapılan çalışmalar olduğu görülmektedir (Altıkulaç ve Uslu, 2014; Hatipoğlu ve Kavas, 2016; Şahan, 2011; Şahin ve Toraman, 2014; Turan, 2017; Yaldız ve Özbek, 2018)

$\mathrm{Bu}$ çalışmanın amacı velilerin lise düzeyindeki tarih derslerine yönelik beklentilerini ortaya koymaktır. Araştırmanın genel amacı çerçevesinde öğrencilerin tarih derslerinde hangi bilgi, beceri ve değerleri kazanması gerektiği yönünde velilerin görüşleri ortaya konularak bunlar belli temalar altında birleştirilmiştir.

\section{Yöntem}

\section{Araştırmanın Deseni}

$\mathrm{Bu}$ çalışmada nitel araştırma paradigması benimsenerek ortaöğretim öğrenci velilerinin görüşleri alınmıştır. Yarı yapılandırılmış veri toplama aracı kullanılarak elde edilen bulgular içerik analizi yapılarak kodlanmış ve bu kodlar temalandırılmıştır. Bu yolla verinin kavramsallaştırılması ve olguyu tanımlayacak temaların ortaya çıkarılması amaçlanmaktadır. Sonuçlar betimsel bir anlatımla sunularak sık sık doğrudan alıntılara yer verilmiştir (Yıldırım ve Şimşek, 2018).

\section{Çalışma Grubu}

Araştırma için 2018-2019 eğitim-öğretim yılının ikinci yarıyılında Yozgat Merkez Illçe, Yozgat Yerköy ilcçesi ile Yozgat Sorgun İlçesinde toplam 15 resmi ortaöğretim kurumu belirlenmiştir. Bu okullarda görev yapan tarih öğretmenleri vasıtasıyla açık uçlu 3 sorudan oluşan yarı yapılandırılmış veri toplama formları öğrenci velilerine ulaştırılmış ve toplam 983 veliden veri toplanmıştır. Bu çalışmayı yapmak için Yozgat Valiliği il Milli Eğitim Müdürlüğünden 25.04.2019 tarih ve E.8304501 sayılı yasal izin alınmıştır. 
Tablo 1

Velilere Ait Demografik Bilgiler

\begin{tabular}{|c|c|c|c|}
\hline & & $n$ & $\%$ \\
\hline \multicolumn{4}{|l|}{ Cinsiyet } \\
\hline & Kadın & 413 & 42,1 \\
\hline & Erkek & 567 & 57,9 \\
\hline & Ceapsız & 3 & \\
\hline \multicolumn{4}{|c|}{ Yaş Grubu } \\
\hline & $18-25$ & 11 & 1,1 \\
\hline & $26-33$ & 41 & 4,2 \\
\hline & $34-41$ & 381 & 39 \\
\hline & $42-49$ & 412 & 42,1 \\
\hline & $50+$ & 132 & 13,6 \\
\hline & Cevapsız & 6 & - \\
\hline \multicolumn{4}{|c|}{ Öğrenim Durumu } \\
\hline & ilköğretim & 303 & 30,9 \\
\hline & Ortaöğretim & 410 & 41,9 \\
\hline & Ön Lisans & 98 & 11 \\
\hline & Lisans & 147 & 15 \\
\hline & Y. Lisans & 19 & 0,2 \\
\hline & Doktora & 1 & 0,01 \\
\hline & Cevapsız & 5 & \\
\hline \multicolumn{4}{|c|}{ Meslekler } \\
\hline & Ev Hanımı & 324 & 34,1 \\
\hline & Çiftçi & 79 & 8,3 \\
\hline & Esnaf & 72 & 7,6 \\
\hline & Öğretmen & 75 & 7,9 \\
\hline & Memur/iş̧̧̧i & 175 & 18,5 \\
\hline & Emekli & 39 & 4,1 \\
\hline & Diğer Meslekler & 186 & 19,5 \\
\hline & Cevapsız & 33 & - \\
\hline Toplam & & 983 & \\
\hline
\end{tabular}

İlk olarak çalışmaya katılan velilerin demografik durumları incelenmiştir. Bu kapsamda çalışmaya katılan velilerin çoğunluğunu erkekler oluşturmaktadır. Ayrıca 42-49 yaş aralığındaki velilerin yaş grubundaki oranı diğerlerine göre daha yüksektir. Öğrenim durumunda ortaöğretim mezunu veliler, meslek grubunda ise ev hanımı olan veliler daha yüksek orana sahip bulunmaktadır.

Tablo 2

Çalışmaya Katılan Okulların Dağılımı

\begin{tabular}{lcc}
\hline Okullar & $\mathbf{n}$ & \% \\
\hline Fen Lisesi & 358 & 36,4 \\
Anadolu Lisesi & 287 & 29,2 \\
Mesleki ve Teknik Lise & 242 & 24,6 \\
Imam Hatip Lisesi & 96 & 9,8 \\
$\quad$ Toplam & 983 & \\
\hline
\end{tabular}


Okulların çalışmaya katılım oranları incelendiği zaman Tablo 2'de görüldüğü üzere en yüksek veli katılımı Fen liselerinden gelmiştir. Bunu sırayla Anadolu Liseleri ve Mesleki ve Teknik Liseler takip etmektedir. En az katılım ise İmam-Hatip Liselerindedir.

\section{Veri Toplama Araçları}

$\mathrm{Bu}$ çalışmada verilerin toplanması için yarı yapılandırılmış veri toplama formu oluşturulmuş ve tarih dersi ile ilgili görüşlerine başvurmakve cevaplarını analiz etmek amacıyla velilere aşağıdaki sorular yöneltilmiştir.

Lisede 4 yıl tarih dersi alan çocuğunuzdan hangi bilgileri kazanmasını beklersiniz?

Lisede 4 yıl tarih dersi alan çocuğunuzdan hangi becerileri kazanmasını beklersiniz?

Lisede 4 yıl tarih dersi alan çocuğunuzdan hangi değerleri kazanmasını beklersiniz?

\section{Verilerin Analizi}

Araştırmada, veri toplama formundan elde edilen verilerin çözümlenmesinde içeriz analizi tekniği kullanılmıştır. Bu amaçla toplanan verilerin önce kavramsallaştırılması, daha sonra da ortaya çıkan kavramların mantıklı bir biçimde düzenlemesi yapılarak kavramları açıklayan temalar belirlenmiştir (Yıldırım ve Şimşek, 2018: 242). Araştırmada elde edilen verilerden bir dizi kategori oluşturulup, sonra da bu kategorilerin her birine giren durumlar sayılarak kaydedilmiştir (Silverman, 2018: 162).

Verilerin çözümlenmesinde içerik analizi yöntemlerinden tümevarımcı analiz kullanılmıştır. Tümevarımcı analizin amacı, kodlama yoluyla verilerin altında yatan kavramları ve bu kavramlar arasındaki ilişkileri ortaya çıkarmak amacıyla yapılmaktadır (Yıldırım ve Şimşek, 2018: 242). Öncelikle, yarı yapılandırılmış formlardan elde edilen veriler, 2 tarih öğretmeni tarafından ayrı ayrı okunmuş, verilen cevaplarda ortak noktalar bulunmuş ve ayrı ayrı kodlar oluşturularak bu kodlar karşılaştırılmıştır. Daha sonra kodlardan yola çıkılarak temalar oluşturulmuştur. Analiz sürecinde velilerin isimleri yerine V1, V2, V3, V100, V563, V876... gibi kodlar kullanılmıştır.

\section{Bulgular}

Çalışma sonrası elde edilen veriler çerçevesinde velilerin toplam 6 tema çerçevesinde tarih derslerinden beklentileri ortaya çıkmaktadır. Bu temalar "Türk Tarih Bilgisi", "Genel Tarih Bilgisi”, "Tarih Bilinci", "Vatanseverlik", "Milli Değerler" ve "Tarihsel Düşünme Becerileri” dir. Bu temalar bilgi, beceri ve değer boyutları başlığı altında ayrı ayrı incelenecektir.

\section{Velilerin Bilgi Boyutundaki Beklentilerine Yönelik Bulgular}

Ortaöğretim öğrenci velilerinin çocuklarından bilgi boyutuyla ilgili beklentileri "Türk Tarih Bilgisi" ve "Genel Tarih Bilgisi" şeklinde temalandırılmıştır. Tablo 3' de velilerin Türk tarih bilgisine yönelik beklentileri verilmiştir. 
Tablo 3

Türk Tarih Bilgisi

\begin{tabular}{lc}
\hline Beklentiler & f \\
\hline Türk Tarihini Bilme & 864 \\
Geçmişte Yaşanan Zorlukları Bilme & 170 \\
Kültür, Örf ve Adetleri Bilme & 112 \\
Osmanlı Tarihi & 79 \\
Atatürk & 40 \\
Türkiye Cumhuriyeti Tarihi & 22 \\
Atatürk ilke ve İnkılapları & 17 \\
Padişahlar & 17 \\
Selçuklu Tarihi & 7 \\
Türk-İslam Tarihi & 3 \\
\hline
\end{tabular}

Tablo 3 incelendiğinde "Türk Tarih Bilgisi" temasıyla ilgili 10 farklı beklentinin kodlanmış olduğu görülmektedir. Bunlar içerisinde ilk 5 beklentiye yönelik belirlenen kodlamalar ve veli görüşleri üzerinde durulacaktır.

Velilerin nerdeyse tamamının belirtmiş olduğu beklenti "Türk Tarihini Bilme" şeklinde belirlenen kodlamadır. Çalışmaya katılan veliler bu beklentileri 3 farklı şekilde ifade etmişlerdir. Bunlar "Geçmişini Bilme", "Atalarını/Ecdadını Bilme" ve "Türk Tarihini Bilme" şeklindedir.

"Geçmişini Bilme" şeklinde kodlanan beklentiye yönelik bazı velilerin ifadeleri şöyledir:

Kendi geçmişini bilmesini isterim. Çünkü hiçbir ulusun bireyleri kendi geçmişini bilmeden yaşayamaz (V13).

Geçmişi hakkında detaylı bilgi sahibi olması gerekir (V34).

Geçmişimizi iyi bir şekilde öğrenmesi (V453).

$\mathrm{Bu}$ ifadelerden de anlaşılacağı üzere velilerin geçmiş ve geçmişimiz kavramından kastettikleri Türk tarihidir. Birçok veli beklentilerini yazarken geçmişimizin bilinmesi, hatta ayrıntılı bilinmesi şeklinde ifadelerde bulunmuşlardır. şekildedir:

"Atalarını/Ecdadını Bilme" şeklinde kodlanan beklentiye yönelik bazı veli ifadeleri şu

Atalarının ne yaptığını bilmesi gerekir (V456).

Atalarının zaferlerini başarılarını bilip, öğrensin (V784).

Ecdadını bilmeyen bir insan geleceğe dönük bir şey yapamaz, o yüzden onları iyi tanıması gerekir (V115).

Birçok velinin Türk tarihine vurgu yapmak isterken atalarımız ve ecdadımız kelimesini sıklıkla kullandıkları görülmektedir. Yine bu kavramlar ile Türk tarihi vurgusu ön plana çıkmaktadır. Özellikle velilerden bazıları "atalarını/ecdadını bilmeyen bir insan geleceğe dönük bir şey yapamaz" ifadesini kullanmıştır. 
"Türk Tarihini Bilme" şeklinde kodlanan beklentiye yönelik bazı veli ifadeleri şu şekildedir:

Cumhuriyet öncesi ve sonrası tarihimizi en ince ayrıntısına kadar kavrayarak öğrenmesini istiyorum (V902).

Tarihimizi yüzeysel değil ayrıntıları ile öğrenmesini istiyorum (V97).

Tarihini iyi bilmeli ve anlamalıdır (V341).

Türk milletinin şanlı geçmişini bilmesini isterim (V785).

Bazı veliler doğrudan Türk tarihinin bilinmesini, öğrenilmesini isterim şeklinde ifadeler kullanmışlardır. Özellikle de ayrıntılı bir Türk tarihi bilgisi birçok velinin beklentisidir. Veliler öğrencilerin öncelikle bu bilginin lise düzeyinde kazandırılması gereken ilk bilgi olması gerektiğini düşünmektedirler.

Bu ifadelerin tamamı incelendiği zaman geçmişini, atalarını veya Türk tarihini bilme şeklinde farklı ifadeler kullanmış olsalar da velilerin çocuklarından kazanmalarını bekledikleri ilk beklenti, Türk tarihinin bilinmesidir.

170 veli çocuklarından "Geçmişte Yaşanan Zorlukları Bilme" başlığı ile kodlanan beklenti içerisindedir. Bu başlık ile ilgili velilerden bazılarının ifadeleri şöyledir:

Bu vatanın nasıl kazanıldığını bilmesini isterim (V 21).

Mustafa Kemal Atatürk ve arkadaşlarınınTürk halkı için verdikleri mücadeleyi bilmelidir (V 112).

Bu vatan için ne şehitler verildiğini öğrenme (V 563).

Türk tarihinde yaşanan savaşlar ve mücadeleler özellikle Birinci Dünya Savaşı ve Kurtuluş Savaşı Türk tarihinde önemli bir yer tutmaktadır. Veliler yakın tarihte yaşanan olaylar başta olmak üzere Türk tarihinde yaşanan zorlukların öğrenciler tarafından bilinmesini istemektedirler. Örneğin "bu vatanın nasıl kazanıldığı bilinsin/bilsinler" şeklinde pek çok ifade veliler tarafından kullanılmıştır.

112 veli çocuklarından "Kültür, Örf ve Adetlerini Bilme" başlığı ile kodlanan beklenti içerisindedir. Bu başlık ile ilgili velilerden bazılarının ifadeleri şöyledir:

Eski dönemlerdeki gelenek ve görenekleri bilmesi önemlidir (V 64).

Kültür ve geleneklerimizi bilmeli (V 234).

Türk örf ve adetlerini, nasıl yaşadıklarını bilmelidir (V 653).

Kültür, gelenek, örf ve adetler bir toplumun en önemli kültürel miraslarındandır. Velilerden bir kısmı bu unsurların Türk tarihinin ayrılmaz bir parçası olduğu görüşündedir. Çocukların da bu bilgilere sahip olarak liselerden mezun olmasını istemektedirler.

79 veli çocuklarından "Osmanlı Tarihi" başlığı ile kodlanan beklenti içerisindedir. Bu başlık ile ilgili velilerden bazılarının ifadeleri şöyledir:

Osmanlı tarihini iyi bir şekilde bilmesi gerekir (V 23). 
Osmanlı devletinin nasıl yönetildiğini, adaletini, nasıl gelişerek büyük bir devlet haline geldiğini bilmesini isterim (V 300).

Osmanlı tarihini öğrenmesi çok çok önemli (V 356)

Türk tarihinin çok önemli bir kısmını oluşturan bu dönem velilerin de çocuklarından bilmelerini istedikleri, hatta örnek almaları gerektiğini düşündükleri bir dönemdir. Örneğin bir veli, "Osmanlı'yı yani bu devleti ve nasıl yaşadıklarını, nasıl yönettiklerini bilip öğrensin ki gerçek tarih bilgisi oradadır (V321)" şeklinde bir ifade kullanmıştır.

40 veli çocuklarından "Atatürk" başlığı ile kodlanan beklenti içerisindedir. Bu başlık ile ilgili velilerden bazılarının ifadeleri şöyledir:

Atatürk'ün hayatını herkesin bilmesi lazımdır (V 88).

Atatürk'ü ve silah arkadaşlarını tanıyıp öğrenmeli (V 333).

Atatürk hakkında en ince detayları bile bilmeli (V 601).

Bu çerçevede özellikle Atatürk'ün hayatı ve yaptığı mücadeleler veli beklentileri içerisinde bulunmaktadır. Örneğin bir veli şu ifadeyi kullanmıştır. "Atatürk'ü ve silah arkadaşlarını tanıyıp öğrenmelidir. Özellikle Kurtuluş Savaşında Atatürk'ün mücadelesi iyi bilinmelidir(V75)." şeklindedir.

Tablo 4

Genel Tarih Bilgisi

\begin{tabular}{lc}
\hline Beklentiler & f \\
\hline Tarih Bilgisi & 74 \\
Dünya Tarihi ve Diğer Medeniyetler & 54 \\
Savaşlar & 50 \\
Yakın Tarih Bilgisi & 22 \\
Kronoloji Bilgisi & 11 \\
İslam Tarihi & 11 \\
\hline
\end{tabular}

Tablo 4 incelendiği zaman veliler tarafından ifade edilmiş olan 6 farklı beklenti bulunmaktadır. Bu beklentiler "Genel Tarih Bilgisi" teması adı altında birleştirilmiştir. Bu beklentilerden ilk 3'ü hakkında değerlendirme yapılacaktır.

74 veli çocuklarından "Tarih Bilgisi” başlığı ile kodlanan beklenti içerisindedir. Bu başlık ile ilgili velilerden bazılarının ifadeleri şöyledir:

Geçmişte neler yaşandığını bilme (V 98).

Tarihi olaylar hakkında bilgi sahibi olmalıdır (V 145).

Tarih hakkında bir konuda kendi görüşünü savunabilecek yeterli bilgiye olsun (V 678).

Velilerden bir kısmı çok genel bir ifade olarak tarih bilgisi, tarih bilgisine sahip olma şeklinde beklentilerini ifade etmişlerdir. Örneğin bir velinin ifadesi, "Geçmişte yaşanan tarihe damga vurmuş olayların hepsini öğrensin (V 451)." şeklindedir. 
54 veli çocuklarından "Dünya Tarihi ve Diğer Medeniyetler" başlığı ile kodlanan beklenti içerisindedir. Bu başlık ile ilgili velilerden bazılarının ifadeleri şöyledir:

Farklı devletlerin ve milletlerin tarihini bilmelidir (V 99).

Eskiden yaşamış uygarlıkları bilme (V 399).

Diğer dünya devletlerinin yakın ve uzak tarihleri hakkında genel çerçeve bilgileri edinmesi iyi olur (V 567).

İnsanlığın ilk dönemlerinden itibaren ortaya çıkan tarih ve medeniyetler velilerin bir kısmı tarafından beklenti olarak vurgulanmıştır. Özellikle veliler eski uygarlıkların öğrenciler tarafından tanınmasını, çocukların bu konuda genel olarak bilgi sahibi olmalarını istemektedirler.

50 veli çocuklarından "Savaşlar" başlığı ile kodlanan beklenti içerisindedir. Bu başlık ile ilgili velilerden bazılarının ifadeleri şöyledir:

Birinci ve İkinci Dünya Savaşını bilme (V 13).

Geçmişte yapılan savaşlar ve sonuçlarını bilmesi, öğrenmesi gerek diye düşünüyorum (V 125).

Geçmişimizdeki savaşları, mağlubiyetleri bilse çok iyi olur (V 789).

Velilerin bir kısmı hem Türk tarihinde hem de dünya tarihinde çok önemli bir yere sahip olan savaşların bilinmesini istemektedirler. Bu konuda velilerin özellikle Birinci ve İkinci Dünya Savaşı ile Kurtuluş Savaşı konularına yoğunlaştıkları görülmektedir. Örneğin bir öğrenci velisi "Çanakkale, Kurtuluş Savaşı ayrıca Dünya savaşlarını bilmesi çok önemlidir (V 112)." ifadesini kullanmıştır.

\section{Velilerin Beceri Boyutundaki Beklentilerine Yönelik Bulgular}

Ortaöğretim öğrenci velilerinin çocuklarından beceri boyutuyla beklentileri Tablo 5 'de verilmiştir.

Tablo 5

Tarihsel Düşünme Becerileri

\begin{tabular}{lc}
\hline Beklentiler & f \\
\hline Objektif Tarih Bilgisine Ulaşma & 61 \\
Tarihi Olayları Yorumlama & 23 \\
Empati Kurabilme & 4 \\
\hline
\end{tabular}

Tablo 5 incelendiğinde "Tarihsel Düşünme Becerileri" adıyla temalaştırılan beklentilerin yalnızca 3 tane olduğu ve bunların da çok az veli tarafından ifade edildiği görülmektedir.

61 veli çocuklarından "Objektif Tarih Bilgisine Ulaşma” başlığı ile kodlanan beklenti içerisindedir. Bu başlık ile ilgili velilerden bazılarının ifadeleri şöyledir:

Doğru tarih bilgisi nedir, ne değildir? Öğrenmesi gerekir (V 234).

Tarihi objektif ve gerçekçi öğrenme yollarını, becerisini kazanması (V 546). 
Tarihi en iyi ve en doğru şekilde öğrenip, uygulamalıdır (V 967)

$\mathrm{Bu}$ ifadelerden anlaşılacağı üzere veliler öğrencilerin doğru yöntemleri kullanarak doğru tarih bilgisine ulaşmalarını gerekli görmektedir. Burada ifade edilen beklentiler ise ancak tarihsel düşünme becerileri yoluyla elde edilebilir. Örneğin bir öğrenci velisi bu başlık ile ilgili olarak, "Tarihle ilgili kesin, net, belgeye dayalı, objektif, tarafsız bilgiler edinebilmelidir (V 403)" şeklinde bir ifade kullanmıştır.

23 veli çocuklarından "Tarihi Olayları Yorumlama" başlığı ile kodlanan beklenti içerisindedir. Bu başık ile ilgili velilerden bazılarının ifadeleri şöyledir:

Tarihi olayları muhakeme edebilme (V 456).

Günümüzde gerçekleşen güncel olayları değerlendirip yorumlayabilmelidir (V 478).

Tarihi olaylar ile ilgili özgürce eleştiriler yapabilme becerisi kazansın (V 567).

Bazı velilerin bu ve buna benzer ifadeler kullanmaları tarih derslerinin ana amaçlarından biri olan tarihsel düşünme becerilerine vurgu yapmaktadır. Tarihi olayları yorumlama başlığı da bunlar içerisinde yer almaktadır.

4 veli ise çocuklarından "Empati Kurabilme" başlığı ile kodlanan beklenti içerisindedir. Çok önemli bir beceri olmasına rağmen yalnızca 4 veli tarafından bu beklenti ifade edilmiştir. Örneğin bir velinin bu konuda yazmış olduğu ifade, "Olayları o günün şartlarını göz önünde bulundurarak değerlendirebilsin, o beceriyi kazansın (V 893)" şeklindedir.

\section{Velilerin Değer Boyutundaki Beklentilerine Yönelik Bulgular}

Velilerin değer başlığı altında ortaya çıkan beklentileri "Tarih Bilinci", "Vatanseverlik" ve "Milli Değerler" temaları altında birleştirilmiştir.

Tablo 6

Tarih Bilinci

\begin{tabular}{lc}
\hline Beklentiler & $\mathbf{f}$ \\
\hline Geçmişten Ders Çıkarma & 231 \\
Geçmişini Bilerek Geleceğine Yön Verme & 202 \\
Tarih Bilinci/Milli Bilinç & 117 \\
Cumhuriyet/Demokrasi/Bağımsızlık & 10 \\
\hline
\end{tabular}

Tablo 6 incelendiği zaman değer boyutuyla ilgili ilk belirlenen temanın "Tarih Bilinci" teması olduğu görülmektedir. Veli beklentileri içerisinde önemli bir yere sahip olan bu başlık içerisinde özellikle Geçmişten ders çıkarma ve geleceğine yön verme beklentisi ön plana çıkmaktadır.

231 veli çocuklarından "Geçmişten ders çıkarma" başlığı ile kodlanan beklenti içerisindedir. Bu başlık ile ilgili velilerden bazılarının ifadeleri şöyledir:

Geçmişte yapılan hatalardan ve başarılardan ders çıkarmalıdır (V 268).

Geçmişten ders alıp aynı hatalara düşmemesini isterim (V 567).

Tarihi şahsiyetlerden örnek, ders alınmalı (V 745). 
Geçmişten ders çıkarma veya tarihten ders çıkarma şeklinde veliler tarafından ifade edilen görüşler incelendiğinde velilerin tarihe yükledikleri anlamda ortaya çıkmaktadır. Veliler geçmişin ancak ders çıkarılabilirse faydalı olacağını diğer bir ifade ile tarihi öğrenmenin temel amacının tarihten ders çıkarma olduğunu düşündükleri anlaşılmaktadır. Ayrıca geçmişte yapılan hataların tekrarlanmamasıdır. Örneğin bir veli "Geçmişten ders çıkarmalıdır bu da ancak geçmişi, atalarını, neler yaptıklarını bilerek onların yaptıkları hataları yapmama şeklinde olur, olmalıdır (V 15)" şeklinde bir ifade kullanmıştır.

202 veli çocuklarından “Geçmişini Bilerek Geleceğine Yön Verme” başlığı ile kodlanan beklenti içerisindedir. Bu başlık ile ilgili velilerden bazılarının ifadeleri şöyledir:

Bir öğrenci tarihi, geçmişini iyi bilirse geleceğe daha iyi hazırlanır (V 5).

Geçmişten çıkardığı bilgilerle geleceğine yön vermesi (V 231).

Tarihten çıkardığı ders ile yolunu çizebilecek bir birey olmasını isterim (V 901).

Velilerden bir kısmı geçmişin/geçmişimizin öğrenciler için bir nevi yol haritası olduğunu düşünmektedirler. Örneğin bir veli, "Geleceğimize güvenle bakabilmek için geçmişte yaşadığımız olayları bilmeli, öğrenmeli, kavramalıdır (V 245)" şeklinde bir ifade kullanmıştır.

117 veli çocuklarından "Tarih Bilinci/Milli Bilinç" başlığı ile kodlanan beklenti içerisindedir. Bu başlık ile ilgili velilerden bazılarının ifadeleri şöyledir:

Tarih bilinci kazanma (V 88).

Tarih şuuru (V 456).

Tarih şuurunu bilerek dostu kim düşmanı kim bilmesini isterim (V 800).

Milli şuur ve benliği kazanma (V 945).

Velilerin tarih bilinci kavramına yükledikleri anlam bilinçli, şuurlu birey olma bunun da öğrencilerin geçmişi hakkında bilinçli, bilgili bireyler olmaları şeklindedir. Örneğin bir veli "Tarihi hakkında, geçmişi hakkında bilinç kazansın, bilinçli olsun (V 643)" şeklinde bir ifade kullanmıştır.

Tablo 7

Vatanseverlik

\begin{tabular}{lc}
\hline Beklentiler & $\mathbf{f}$ \\
\hline Vatanını/Milletini Sevme & 163 \\
Vatana/Millete Faydalı Olma & 40 \\
Bayrak Sevgisi & 22 \\
Milli Birlik ve Beraberlik Düşüncesi/Vatandaşlık Duygusu & 15 \\
\hline
\end{tabular}

Tablo 7 incelendiği zaman 163 velinin çocuklarından "Vatanını, Milletini Sevme” başlığı ile kodlanan beklenti içerisinde olduğu görülmektedir. Bu başlık ile ilgili velilerden bazılarının ifadeleri şöyledir:

Vatanına sahip çıkma (V 221).

Vatan, millet sevdalısı bir birey olması en büyük isteğim ( $V$ 455). 
Vatanımızın ne kadar kıymetli olduğunu bilip, öğrenmeli (V 499).

Vatanını sevme, sahip çıkma, kıymetini bilme, vatan-millet sevdalısı olma şeklinde farklı ifadelerle veliler tarafından belirtilen bu beklenti toplumsal kaynaşmayı sa ğlayan en önemli unsurlardan biri olan vatanseverlik değerini veli bakış açısıyla ortaya koymaktadır.

40 veli çocuklarından "Vatana, Millete Faydalı Olma" başlığı ile kodlanan beklenti içerisindedir. Bu başlık ile ilgili velilerden bazılarının ifadeleri şöyledir:

Ülkesi için her zaman fedakârlık yapma düşüncesinde olmalı (V 134).

Vatana, millete faydalı işler yapma (V 409).

Vatanına ve milletine minnettar olmalıdır (V 607).

Son olarak 180 veli ise çocuklarından "Milli/Manevi/Ahlaki/ Değerlere Sahip Olma” başlığı ile kodlanan beklenti içerisindedir. Bu başlık ile ilgili velilerden bazılarının ifadeleri şöyledir:

Değerlerimizi bilmeli, yaşamalı (V 78).

Milli değerleri tanıması ilk kazanması gereken şeylerden (V 109).

Milli, manevi, ahlaki ve dini değerlerin önemini bilme (V 346).

\section{Sonuç}

$\mathrm{Bu}$ çalışmada ortaöğretim öğrenci velilerine 4 yıl süresince tarih dersi alan çocuklarından hangi bilgi, beceri ve değerleri kazanmalarını bekledikleri sorulmuş ve çalışma sonucunda velilerin daha çok bilgi ve değer yönüyle beklentilerini sıraladıkları görülmüş, öğrenci velilerinin beceriye yönelik beklentilerinin sınırlı kaldığı belirlenmiştir.

Bilgi ve değer beklentileri daha çok disiplin dışı amaçlar (Dilek, 2007: 26) adıyla nitelenen tarih öğretim programında yer alan amaçlarla ilgilidir. Beceri beklentileri ise disiplin içi amaçlarla (Dilek, 2007: 25) ilgilidir. Ortaöğretim tarih müfredat programında yer alan genel amaçlar hem disiplin içi hem de disiplin dışı amaçlara yer vermektedir (MEB, 2018).

Araştırmaya katılan velilerin tamamına yakını çocuklarının Türk tarihini bilmesini istemektedir. Velilerin daha çok Türk tarihine vurgu yapması tarih öğretim programının amaçları ile de uyumludur. Çünkü Öğretim programının içeriği hazırlanırken kavram ve olgulara dair soyut temalara ilişkin somut tarihî örneklerde Türk, İslam ve Anadolu tarihlerine ağırlık verilmiştir. Bu bakış açısı çerçevesinde içeriğin sunumunda insanlık tarihinin birikimi Türk ve Türkiye tarihinden seçilen olaylar merkezinde ele alınmıştır (MEB, 2018).

Cumhuriyet döneminde etkin tarih anlayışı ulusal düşünceye ağırlık veren yapıdadır (Oral, 2019: 283). Türk tarihine yüksek oranda yapılan vurgu ulusal tarih anlayışının ortaöğretim öğrenci velilerinde de mevcut olduğunu göstermektedir. 
Bilgi başlığı altında bulunan veli beklentilerinden "Kültür, Örf ve Adetler, Osmanlı, Atatürk, Türkiye Cumhuriyeti, Atatürk İlke ve İnkılapları, Padişahlar, Selçuklu tarihi ve Türkİslam tarihi" Türk tarihi konusu içine giren diğer beklentiler içerisindedir.

Bilgi başlığı altında velilerin "Genel Tarih Bilgisi” teması altında birleştirilen beklentileri bulunmaktadır. Bunlar içerisinde en yüksek oranı çok genel bir ifade olarak ortaya çıkan tarih bilgisi beklentisidir. Ayrıca dünya tarihi, savaşlar, yakın tarih bilgisi, kronoloji bilgisi ve i̇slam tarihi diğer beklentiler içerisindedir.

Velilerin bilgi boyutunda Türk tarihinin öğrenilmesine yönelik yüksek oranda beklentileri dışında en yüksek beklenti değerler başlığı içerisinde geçmektedir. Bu başlık içerisinde "Geçmişten ders çıkarma" velilerin en fazla vurguladıkları beklentidir. Veliler tarih öğreniminin geçmişten ders çıkarılmasını sağlamakamacına yönelik olduğu düşünmektedirler. Bu sonuç daha önce öğrencilere yönelik yapılan (Demircioğlu, 2006; Safran, 2006; Tekeli, 2017) çalışmaların sonuçlarıyla örtüşmektedir. Yine tarih öğretmenlerinin beklentilerine yönelik Demircioğlu'nun (2004) yaptığı çalışmada da benzer sonuçlara ulaşılmıştır.

Bunun dışında veliler değerler başlığı altında "Geçmişini Bilerek Geleceğine Yön Verme", "Vatanını, Milletini Sevme", "Tarih Bilinci/Milli Bilinç", "Vatana, Millete Faydalı Olma", "Milli Birlik ve Beraberlik Düşüncesi ve Vatandaşlık Duygusu" ile "Bayrak Sevgisi" başlıkları ile belirlenmiş olan beklentilerini değer başlığı altında sıralamışlardır. Değerler içerisinde vurgulanan beklentilerin tamamına yakını öğretim programlarında kök değerler içerisinde sayılan "vatanseverlik" değeri ile doğrudan ilgilidir.

Öğrenci velilerinin bir kısmı çocuklarının Türk tarih bilgisi teması içerinde değerlendirilen "Geçmişte Yaşanan Zorlukları Bilme" başlığıyla belirlenen beklenti içerisindedir. Bunun vurgulanmış olması Türk halkının 1. Dünya Savaşı ve Kurtuluş Savaşlarında yaşanan zorlukları genç nesillerinde bilmesini istedikleri ve bu beklentinin aslında "geçmişten ders çıkarma" ve "geçmişini bilerek geleceğine yön verme" başlığı ile belirlenen beklentiyle birlikte değerlendirilebileceğini göstermektedir. Velilerin bir kısmına göre bu iki değer geçmişte yaşanan zorlukların bilinmesi sonrasında kazanılabilmektedir.

Ortaöğretim öğrencilerinin kazanması gereken değerlere ilişkin yapılan bir çalışmada elde edilen bulgulara göre, veliler, okulun çocuklarına insani, milli ve manevi değerleri kazandırmasını beklemektedirler. Bunlar içerisinde vatan, millet ve tarih sevgisi ile din ve aile kavramlarının öğretimi velilerin değer bağlamında en çok üzerinde durdukları konu olmuştur (Selvitopu, Bora, ve Taş, 2014: 989). Yapılan bu çalışma sonucunda da bu çalışmaya benzer sonuçlara ulaşıldığı söylenebilir.

Tarih öğretiminin temel amaçlarından biri de öğrencilerde tarihsel düşünme becerilerinin geliştirilmesidir. (Erinç, 2003:7) Gerek tarihsel düşünme becerileri gerekse daha kapsayıcı nitelikte olan tarih okuryazarlığı becerilerinde öğrenciyi öğrenme sürecinde aktif kılacak çeşitli yöntem ve tekniklere dayalı bir öğretim süreci öngörülmektedir (Keçe, 2015: 116).

Bu çalışma sonrasında veli beklentilerinin çok azının tarihsel düşünme becerilerine yönelik olduğu sonucuna ulaşılmıştır. Bunlar içerisinde objektif tarih bilgisine ulaşma en yüksek beklentiyi oluştururken, bunu tarihi olayları yorumlama beklentisi izlemektedir. Yalnızca sınırlı 
sayıda veli ise en önemli tarihsel düşünme becerilerinden olan tarihsel empati konusuna değinmiştir. Bu eksikliğin bu işin yürütücüsü olan tarih öğretmenlerinde de bulunduğu bilinmektedir. Örneğin Demircioğlu'nun (2009) yaptığı çalışma da tarihsel düşünme becerilerinin öğrencilere kazandırılması ve geliştirilmesinde kullanılacak öğretim strateji, yöntem ve teknikler açısından, tarih öğretmenlerinin yeterli bilgi ve deneyim sahibi olmadıkları sonucuna ulaşılmıştır.

Sonuç olarak veliler bilgi ve değer kazanımı açısından yüksek beklentiye sahipken beceri anlamında bu beklenti neredeyse yok denecek kadar azdır. Ayrıca genel anlamda öğretim programlarındaki genel amaçlar açısından beceri boyutuyla veli beklentilerinin örtüşmediği görülmektedir. Velilerin beklentileri ile müfredat amaçları arasındaki uyum tarih derslerinde istenen verimliliği de artıracaktır. Bu çalışma Yozgat ili ile sınırlıdır. Farklı illerde yapılacak buna benzer çalışmalara ihtiyaç olduğu söylenebilir.

\section{Kaynakça}

Altıkulaç, A., ve Uslu, S. (2014). Sosyal bilgiler dersinden beklentilerin karşılaştırılması. Turkish Studies, 9(7), s. 165-175.

Altun, S. A. (2009). İlköğretim öğrencilerinin akademik başarısızlıklarına ilişkin veli, öğretmen ve öğrenci görüşlerinin incelenmesi. Elemantary Education Online, 8(2), s. 567-586.

Anık, C. (2006). Bilgi sosyolojisine göre bilginin işlevi ve bir model denemesi. Bilig, Güz(39), s. 1-29.

Argon, T., ve Kıyıcı, C. (2012). İlköğretim kurumlarında ailelerin eğitim sürecine katılımlarına yönelik öğretmen görüşleri. Dicle Üniversitesi Ziya Gökalp Eğitim Fakültesi Dergisi, 19, s. $80-95$.

Arslanargun, E. (2007). Okul aile işbirliği ve öğrenci başarısı üzerine bir tarama çalışması. Sosyal Bilimler Dergisi, 18, s. 120-135.

Aydın, M. (2008). Bilgi sosyolojisi ve toplumumuzun bilgi sistemi. Türkiye Araştırmaları Literatür Dergisi, 6(11), s. 195-222.

Babaoğlan, E., Çelik, E., ve Nalbant, A. (2018). İdeal öğrenci velisi üzerine nitel bir çalışma. EUluslararası Eğitim Araştırmaları Dergisi, 9(1), s. 51-65. DOi: 10.19160/ijer.370497

Demircioğlu, i. H. (2004). Tarih ve coğrafya öğretmenlerinin sosyal bilimler öğretiminin amaçlarına yönelik görüşleri (Doğu Karadeniz örneği). Bilig, Güz (31), s. 71-84.

Demircioğlu, ì. H. (2006). Lise öğrencilerinin tarih dersinin ama çlarına yönelik görüşleri. Eğitim Bilimleri Dergisi, 4(2), s. 153-164.

Demircioğlu, ì. H. (2009). Tarih öğretmenlerinin tarihsel düşünme becerilerine yönelik görüşleri. Milli Eğitim, Güz (184), s. 228-239.

Demircioğlu, i. H., ve Tokdemir, M. (2008). Değerlerin oluşturulma sürecinde tarih eğitimi: Amaç, işlev ve içerik. Değerler Eğitimi Dergisi, 6(15), s. 69-88. 
Dilek, D. (2007). Tarih derslerinde öğrenme ve düşünce Gelişimi (3 b.). Ankara: Nobel.

Dinçer, M. (2002). Cumhuriyetin ilanından bu yana eğitimde verimlilik konusuna bir bakış. Ege Eğitim Dergisi, (2)1, s. 34-46.

Döş, İ. (2011). Ortaöğretim öğrencilerinin başarısızlık nedenlerine ilişkin öğretmen görüşleri. Milli Eğitim, Bahar (190), s. 72-91.

Erdem, A. R. (2003). Üniversite kültüründe önemli bir unsur: Değerler. DeğerlerEğitimi Dergisi, $1(4)$, s. 55-72.

Hatipoğlu, A., ve Kavas, E. (2016). Veli yaklaşımlarının öğretmen performansına etkisi. Insan ve Toplum Bilimleri Araştırmaları Dergisi, 5(4), s. 1012-1034.

Healstead, J., ve Taylor, M. (2000). Learning and teaching about values: A review of recent research. Cambridge Journal of Education, 30(2), s. 169-202.

Historical Thinking Standards. (2019). Erişim (01/12/2019): https://phi.history.ucla.edu./nc hs/ historical-thinking-standars/

Işık, H. (2008). Tarih öğretiminde doküman kullanımının öğrencilerin tarihsel düşünme becerilerine ve başarılarına etkisi (Yayımlanmamış doktora tezi). Gazi Üniversitesi, Eğitim Bilimleri Enstitüsü, Ankara.

Karabağ, G. (2002). Tarih öğretmeninin mesleki bilgi ve becerilerini şekillendiren unsurlar. Gazi Eğitim Fakültesi Dergisi, 22(1), s. 211-215.

Keçe, M. (2015). Tarihsel düşünme becerileri ile tarih okuryazarlığı becerilerinin karşılaştırılması. Karadeniz Sosyal Bilimler Dergisi, 7(3), s. 108-122.

Oral, M. (2019). Türkiye'de romantik tarihçilik. İstanbul: Yeni İnsan.

Milli Eğitim Bakanlığı Öğretim Programları. (2018). Erişim (12/11/2019): http://mufredat.meb.gov.tr/ProgramDetay.aspx?PID=344

Öztürk, M., ve Mutlu, N. (2017). Sosyal bilgiler ve tarih derslerinde beceri ve değerlerine kadar öğretiyoruz? Özgün Araştırma, 7(3), s. 552-563.

Safran, M. (2006). Lise öğretmen ve öğrencilerine göre tarih dersinin amaçları. Tarih Eğitimi Makale ve Bildiriler (s. 13-17). Ankara: Gazi.

Selvitopu, A., Bora, V., ve Taş, A. (2014). Ortaöğretim öğrencilerine kazandırılması gereken değerlere ilişkin velilerin okuldan beklentileri. Kastamonu Eğitim Dergisi, 23(3), s. 979994.

Silverman, D. (2018). Nitel verileri yorumlama (5 b.). (Çeviri Editörü: Erkan Dinç). Ankara: Pegem Akademi.

Şahan, M. A. (2011). ilköğretim okullarında öğrencisi olan velilerin yönetici ve öğretmenlerden beklentileri (Yayımlanmamış yüksek lisans tezi). Pamukkale Üniversitesi, Sosyal Bilimler Enstitüsü, Denizli.

Şahin, A., ve Toraman, M. (2014). İlköğretim müzik dersine yönelik veli ve öğrenci görüşleri. Türkiye Sosyal Araştırmaları Dergisi, 14(1), s. 329-345. 
Şahin, H. (2018). Eğitim sürecine veli katılımının bir boyutu olan öğrenmeyi destekleyici ev ortamının veli toplantılarında yer alma durumunun incelenmesi (Yayımlanmamış Yüksek Lisans Tezi). Gaziantep Üniversitesi, Eğitim Bilimleri Enstitüsü, Gaziantep.

Talim Terbiye Kurulu Başkanlığı. (2018). Erişim (04.12.2019): http://ttkb.meb.gov.tr/meb_iys_dosyalar/2018_02/21173451_ort_ogrtm_hdc_2018. pdf

Tatlıŏlu, K. (2016). Okul başarısızlığının nedenleri üzerine bir değerlendirme. Uluslararası Bozok Sempozyumu, 3, s.6-23, Yozgat.

Tekeli, i. (2017). Tarih bilinci ve gençlik (2 b.). İstanbul: Tarih Vakfı.

Topbaş, E. (1997). Milli Eğitimin genel hedefleri ile ilköğretim ikinci kademede okutulan derslerin özel hedefleri arasındaki tutarlılık üzerine bir araştırma (Yayınlanmamış yüksek lisans tezi). Abant İzzet Baysal Üniversitesi, Sosyal Bilimler Enstitüsü, Bolu.

Turan, E. Z. (2017). Din kültürü ve ahlak bilgisi öğretmen yeterlilikleri: Veli beklentileri. Çukurova Üniversitesi Ilahiyat Fakültesi Dergisi, 17(2), s. 185-204.

Turan, R. (2015). Tarih öğretmenlerinin lise tarih derslerinin genel amaçlarının öğrencilere kazandırılma düzeylerine ilişkin görüşleri (Ankara ili örneği). Turkish Journal of Educational Studies, 2(3) s. 139-180.

Türk Dil Kurumu. (2018). Erişim (03.12.2019): https://www.sozluk.gov.tr/

Yaldız, A., ve Özbek, O. (2018). Illköğretim okullarında beden eğitimi dersine yönelik öğrenci ve ana-baba tutumları. Kastamonu Üniversitesi Eğitim Dergisi, 26(1), s. 75-81.

Yıldırım, A., ve Şimşek, H. (2018). Sosyal bilimlerde nitel araştırma yöntemleri (11 b.). Ankara: Seçkin.

Yılmaz, T., ve Sarpkaya, R. (2016). Eğitim ekonomisi (1 b). Ankara: Anı. 